
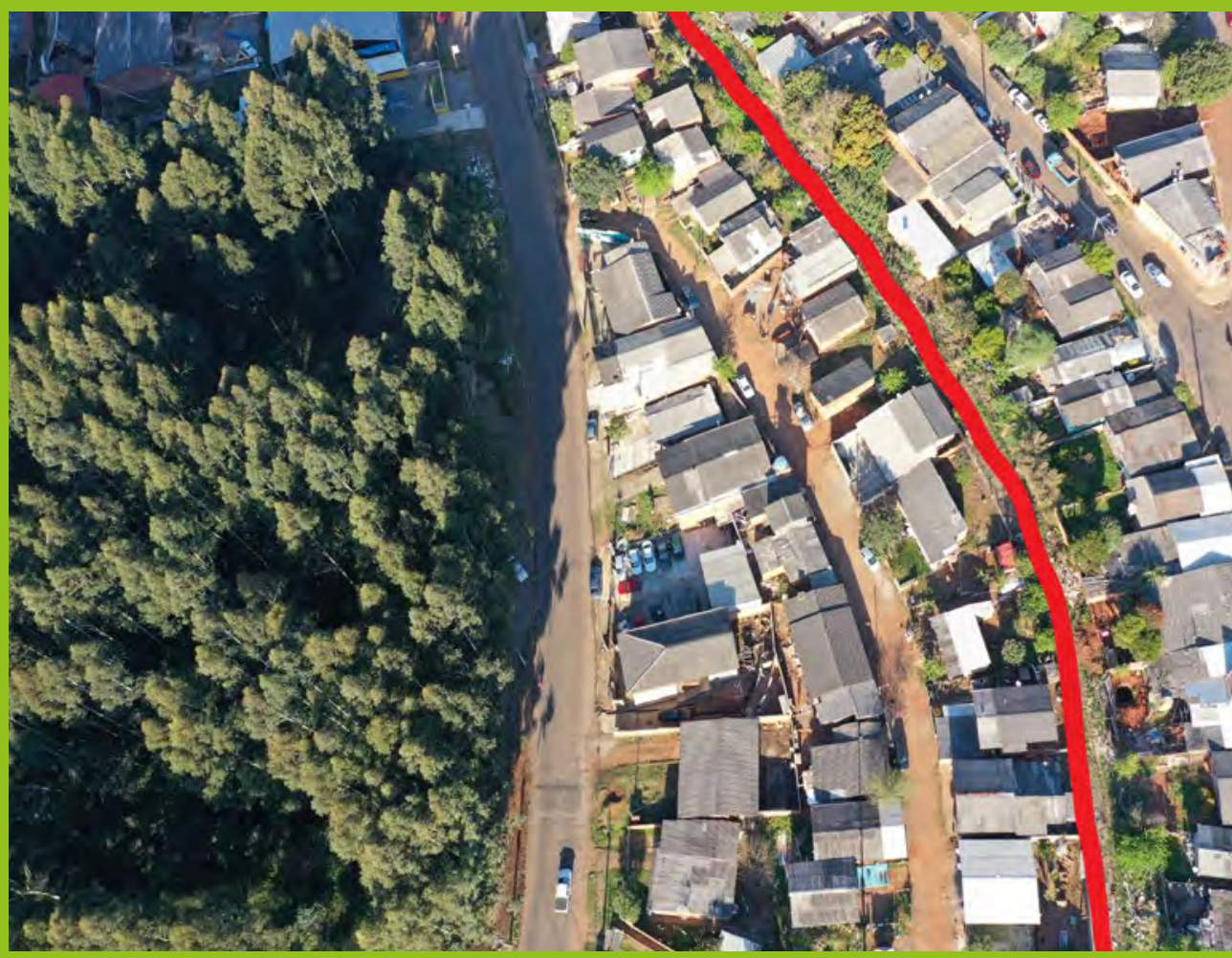

a

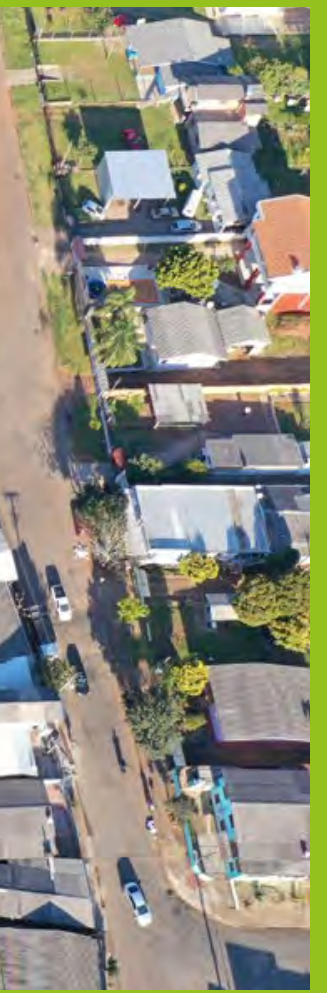

\title{
Beira-Trilhos: a Extensão Universitária e o direito à cidade
}

Marcos Antonio Leite Frandoloso - frandoloso@upf.br ${ }^{1}$

Eduardo Nischespois Scorsatto - enscorsatto@gmail.com²

Natália Costa Boff - nataliacostaboff@hotmail.com³

Daniela Panhossatt - danielapanhossatt@gmail.com ${ }^{4}$

\section{RESUMO}

0 objetivo do Projeto de Extensão Universitária Beira-Trilhos é buscar alternativas que contribuam para a construção do direito à cidade para as populações das ocupações Beira-Trilhos de Passo Fundo/RS, dando continuidade aos processos iniciados em 2005 , com relação aos aspectos jurídicos, urbanísticos e sociais ampliando suas perspectivas e interfaces. Como contribuição para as futuras soluções, foram desenvolvidos estudos de repertorização de casos similares e possíveis alternativas de organização do território. 0 trabalho busca fomentar a discussão desta temática, comum a diferentes comunidades brasileiras com ferrovias dentro de suas áreas urbanizadas, de maneira transversal nas atividades de Extensão Universitária, e também a partir dos pressupostos de sua articulação com o Ensino e a Pesquisa.

PALAVRAS-CHAVE: ocupações urbanas; direito à cidade; direito à moradia. ferrovias urbanas.

1 Dr. Internacional em Energia e Meio Ambiente na Arquitetura - ETSAB/UPC; Professor Faculdade de Engenharia e Arquitetura - Universidade de Passo Fundo - RS.

2 Arquiteto e Urbanista UPF; Mestrando PROPUR-UFRGS, ex-bolsista PAIDEX-UPF.

3 Graduanda em Arquitetura e Urbanismo - UPF; Bolsista PAIDEX-UPF.

4 Graduanda em Arquitetura e Urbanismo - UPF; Bolsista PAIDEX-UPF. 


\title{
Beira-Trilhos: University Extension and the right to the city
}

\begin{abstract}
The Beira Trilhos University Extension Project aims to find alternatives that contribute to the promotion of the right to the city of the Beira Trilhos occupation populations in Passo Fundo/RS. Its purpose is to carry on the processes begun in 2005 in terms of legal, urban, and social aspects, while broadening its perspectives and interfaces. Investigations of repertorization of similar circumstances and various alternatives of territory organization have been done as a contribution to future solutions. Through University Extension activities, as well as the assumptions of their articulation with Teaching and Research, this study attempts to encourage a transversal debate on this subject, which is common to various Brazilian communities with railroads within their urbanized regions.
\end{abstract}

KEYWORDS: urban occupations; right to the city; housing rights; urban railway.

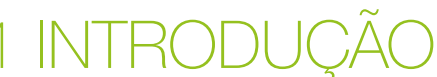

0 presente trabalho tem a premissa de que a prática da Extensão Universitária deve assumir uma postura crítica, capaz de se tornar uma força transformadora para os extensionistas e para o território onde se emerge determinado projeto. Tommasino e Cano (2016) afirmam que a Extensão crítica e ativa permitirá aos participantes promover uma articulação integral das funções universitárias, baseadas nas práticas articuladas com a realidade social.

Nesse sentido, esta realidade social se relaciona com a abrangência que o conceito do direito à cidade carrega em si, nas interpelações da própria cidade e dos direitos, ou seja, que está sempre a estruturar-se.

É desafiador compreender esses fluxos dado que nunca se vê a cidade de fora dela e de fora de si mesmo, ou, então, num estado de tempo estagnado; ao contrário, a experiência de análise é necessariamente um movimento que adentra esse espaço em suas mobilidades e imobilidades, subjetividades e significados (FRANDOLOSO et al., 2019). Assim, "saber que tipo de cidade queremos é uma questão que não pode ser dissociada de saber que tipo de vínculos sociais, relacionamentos com a natureza, estilos de vida, tecnologias e valores estéticos nós desejamos" (HARVEY, 2013) para nossas cidades.

Nas especificidades deste trabalho, esta problemática parte de que no Brasil, por alguns anos, o transporte ferroviário de passageiros e de cargas foi uma infraestrutura que recebeu grandes investimentos públicos, os quais possibilitaram a instalação e expansão desse tipo de mobilidade. Coligadas a essas infraestruturas, não raramente encontram-se áreas inteiras ocupadas por populações que não são reconhecidas no seu direito à moradia e que veem nesse território uma possibilidade de reivindicar o direito à cidade (CDHPF, 2005). "Os casos mais emblemáticos são os assentamentos humanos urbanos fixados na faixa de domínio junto à área operacional considerados de alto risco, uma vez que as casas estão construídas numa faixa perigosamente próximas da via permanente dos trilhos" (CDHPF, 2005, p. 33). Como comenta Maricato (2015), a única alternativa dos pobres vivenciarem o seu direito à cidade é a ocupação destas zonas periféricas, marginalizadas, deterioradas.

Em Passo Fundo, município do Norte do Rio Grande do Sul com uma estimativa populacional de 204.722 habitantes (IBGE, 2020), a realidade não é diferente de outros lugares do País; há mais de quatro décadas ocorrem várias zonas de ocupação que permeiam a malha urbana em uma extensão de aproximadamente $15 \mathrm{~km}$ - Figura 1. Embora a área operacional varie de acordo com o trecho e que alguns domicílios, que estão próximos às ocupações, são locados em áreas não operacionais, as populações que estão dentro do território concedido à operadora da concessão ferroviária são a maioria das ocupantes desse eixo linear (FRANDOLOSO et al., 2019). 


\section{Figura 1 - Território Beira-Trilhos em Passo Fundo.}

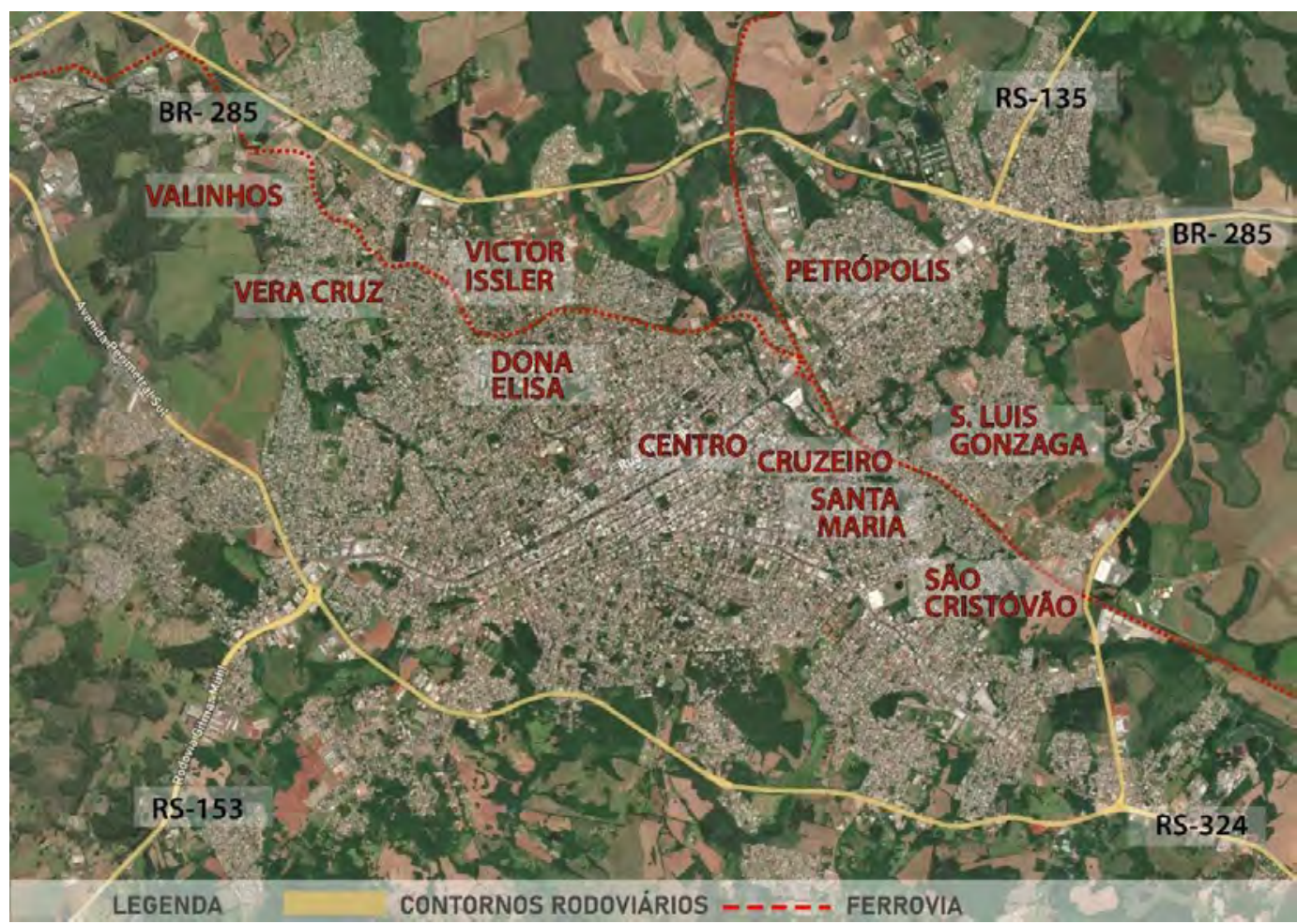

FONTE: autores

0 Projeto de Extensão Beira-Trilhos é fruto de mobilização e organização de diversas entidades e instituições do Município, Estado e País, institucionalizado na Universidade de Passo Fundo desde 2006 coma denominação de "Cidade de Todos" (FRANDOLOSO et al., 2019; FRANDOLOSO; SCORSATTO; VASCONCELLOS, 2019; FRANDOLOSO; SCORSATTO, 2020). Este processo deu origem a um Grupo de Trabalho (GT) instituído pelo Poder Público Municipal que, nos anos seguintes, fez o monitoramento da Pesquisa desenvolvida no início de 2005, na qual se apresentaram dados socioeconômicos, urbanos e geográficos sobre a realidade das ocupações (CDHPF, 2005; KALIL et al., 2007). 0 diagnóstico de 2008 (GT BEIRA-TRILHOS, 2008) apontou 1.086 famílias residindo ao longo do denominado território Beira-Trilhos, atravessando a zona urbana no sentido Leste-Oeste; estima-se que atualmente 1.500 famílias residam nesse território.

0 Projeto de Extensão Beira-Trilhos (CARBONARI; VASCONCELLOS, 2016), na sua configuração atual, dá continuidade aos processos comunitários, quanto aos aspectos jurídicos, urbanísticos e sociais, de maneira a ampliar as suas perspectivas e interfaces, a fim de contribuir para a construção do direito à moradia e à cidade para as comunidades "Beira-Trilhos", Projeto este institucionalizado na Universidade de Passo Fundo (UPF) desde 2017 e inserido na Política de Responsabilidade Social Universitária (DALMOLIN; MORETTO, 2014) e na Política de Extensão e Assuntos Comunitários (UPF, 2017). Estas ações revestem-se na melhoria da qualidade de vida e no respeito às necessidades sociais, culturais e estéticas.

0 Projeto tem como objetivos específicos:

a. o reconhecimento e o fortalecimento do protagonismo dos moradores do território Beira-Trilhos;

b. construir uma proposta de ação interdisciplinar com o envolvimento de diversas áreas de conhecimento acadêmicos e populares;

c. produzir estratégias e práticas que articulem iniciativas de Extensão, Ensino e Pesquisa, de modo a aprofundar a sua indissociabilidade e transversalidade;

d. contribuir na busca de soluções articuladas com os poderes públicos e organizações sociais;

e. complementar o processo formativo dos estudantes, por meio da vivência social e da experiência teórico-prática como um todo, em uma relação transformadora com a sociedade, afirmando o caráter social do ensino universitário.

Para tanto, foram estabelecidas diferentes metas de forma articulada, trans e multidisciplinar, a fim de construir e discutir com as comunidades locais as possibilidades de atuação conjunta na melhoria de questões imediatas e pontuais, através de ações do tipo botton up e/ou hands on, como forma de criar/ reforçar laços e visualizar a força do grupo (FRANDOLOSO; SCORSATTO; VASCONCELLOS, 2019). As metas foram estruturadas em três eixos: 
Monitoramento, que reúne ações de acompanhamento, de forma articulada com os moradores e as instituições parceiras, de órgão governamentais ou não-governamentais, conectando a pesquisa com as atividades extensionistas, como estudos sobre os vazios urbanos e levantamentos socioeconômicos, servindo de subsídios às agendas dos poderes públicos;

Formação, que visa ao fortalecimento da organização das lideranças e das comunidades BeiraTrilhos, no sentido de ampliar seu protagonismo no processo de luta dos agentes sociais associados e a formação complementar de estudantes articulada com o Ensino e a Pesquisa. Neste eixo são desenvolvidas ações como visitas, encontros, curso e seminário sobre Direito à Cidade, Habitação, Saneamento e temas coincidentes. Com relação às ações junto à comunidade, que claramente vinculam-se ao eixo de Formação, elas devem ser flexíveis, apoiadas nas experiências compartilhadas com a comunidade;

Projeto Global, que objetiva a constituição de uma visão global, um projeto de enfrentamento da situação da Beira-Trilhos tendo em vista o envolvimento dos diversos agentes implicados. Aqui são desenvolvidas ações como: visitas de intercâmbio, no sentido de conhecer experiências semelhantes que tenham levado a soluções da problemática Beira-Trilhos, reuniões de trabalho com os agentes implicados e busca por mapeamento de possíveis agentes financiadores. Este também é um eixo de articulação com múltiplos agentes e, apesar de significar a construção definitiva de uma solução para a questão, escapa ao Projeto de Extensão o controle total da ação. Neste eixo, inserem-se as articulações com os cursos parceiros ou colaboradores em ações específicas, em pautas direcionadas, sejam elas técnicas (Engenharia Civil e Engenharia Ambiental e Sanitária, por exemplo) ou de comunicação (Jornalismo) e interação social (Serviço Social, Pedagogia etc.).

As ações propostas, apresentadas na Figura 2, indicam uma reflexão inicial integrada para a resolução de questões pontuais em um processo de interação dialógica. As reflexões destas ações na formação acadêmica de extensionistas e do corpo discente em geral partem da premissa de incorporar as potencialidades da curricularização da Extensão, e atender igualmente às recentes normativas e marco legal para a educação superior (BRASIL, 2018), e aos princípios da indissociabilidade entre Ensino, Pesquisa e Extensão.

Figura 2 - Ações propostas e processo de desenvolvimento alcançados.

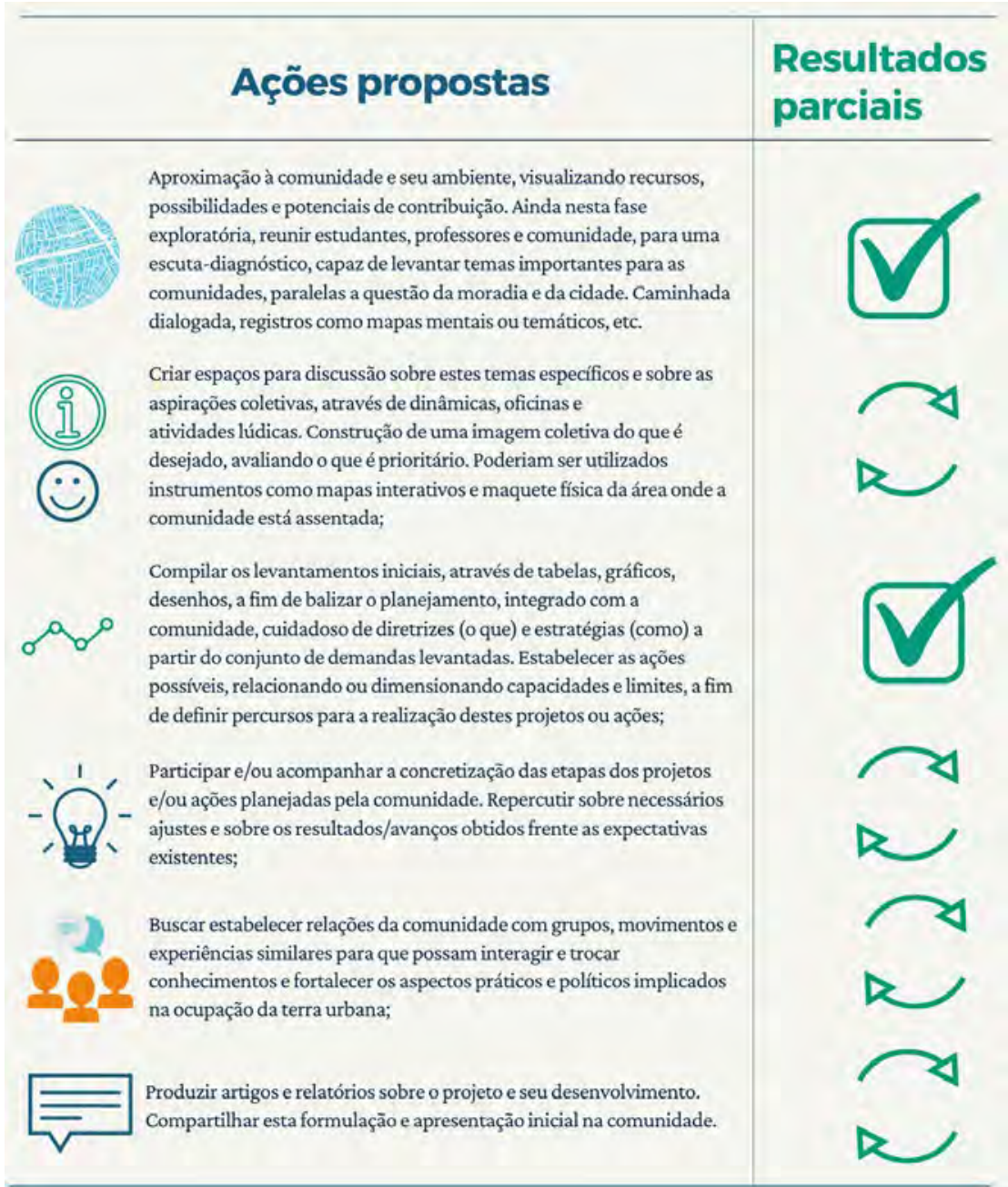

FONTE: autores. 
Para melhor compreensão de como são as propostas de intervenções urbanas em ferrovias é necessário analisá-las, entendê-las como foram pensadas, como foram solucionadas em casos de moradias próximas à linha férrea, e, também, é preciso observar como acontece a relação entre a população, envolvida na situação, e a ferrovia propriamente dita, pois é de suma importância. Dessa forma, foram realizados estudos de casos referentes ao tema, para assim se aprofundar na problemática e assimilar os processos envolvidos, soluções e constituir um embasamento para possíveis propostas de intervenção. A metodologia utilizada para o desenvolvimento apoia-se em estudos bibliográficos, fotografias, comparações, análises de projetos, de problemáticas e suas devidas soluções, além de, discussões em grupo para melhor entendimento, sendo os alunos bolsistas os protagonistas deste processo.

Em um estudo acadêmico de alternativas para a organização do território, foi selecionada uma área como projeto-piloto, envolvendo os agentes sociais externos em articulação com o Projeto de Extensão comunitária; esta alternativa evidencia a conexão da Extensão com a sua indissociabilidade com o Ensino e a Pesquisa.

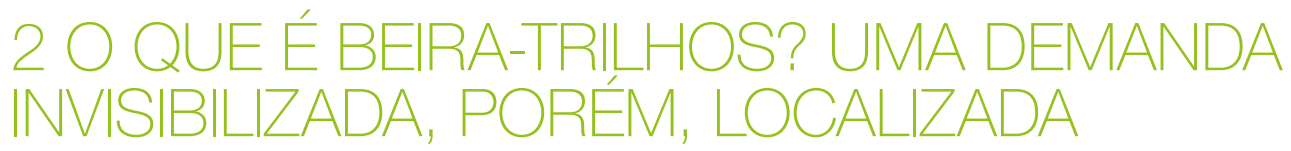

Para a contextualização das temáticas dentro do Projeto de Extensão Universitária Beira-Trilhos, deve-se entender as distintas abordagens e concepções sobre a cidade como "o espaço construído pelo homem que reflete o modo de vida, a cultura, a produção e as relações de uma sociedade, em um determinado período de tempo" (GELPI, KALIL, 2016, p. 38) e não apenas como "uma soma de casas, canos e vias", conforme Rolnik (2017, p. 141).

Neste contexto, a cidade é um espaço integral e permanentemente coletivo. Embora muitas tendências e práticas busquem privatizar, segmentar e individualizar, faz parte da gênese da cidade ser interpessoal, um ambiente de trocas e de comunicação. Logo, se as cidades são a presença e a falta de infraestruturas, equipamentos e tecnologias e ainda o espaço de ser gente (subjetividades, ações e reações humanas), podemos conceber esse como um lugar fecundo para o encontro (SCORSATTO, 2019). Muito embora os direcionamentos do planejamento urbano modernista conformaram as cidades à priorização do automóvel, ainda assim, "as pessoas reúnem-se onde as coisas acontecem e espontaneamente buscam outras pessoas” (GEHL, 2015, p. 25), ou seja. a cidade é um acontecimento comunitário. Comunitária como o é, torna-se indissociável à política - como prática de gestão dos bens comuns.

Adiante disso, vale ressaltar que se poderia tratar a cidade sobre uma infinidade de outras abordagens e aspectos. Desde os estudos da sintaxe espacial, das narrativas urbanas, dos estudos morfológicos, costurados a aspectos regionais, intraurbanos, quantitativos e/ou qualitativos, enfim, absolutamente uma enorme variedade. Contudo, importa aqui tratar da cidade essencialmente como a polis, situada no marco pós-moderno e calcada no neoliberalismo como estilo de vida, sistema econômico e período histórico.

Outra conexão imprescindível é de que os direitos sociais e econômicos pressupõem a existência de situações desiguais entre os seres humanos, e cabem ações das distintas esferas administrativas para buscar o equilíbrio nessas relações. Desta maneira, o direito à cidade só pode ser formulado como direito à vida urbana, transformada, renovada. [...] "se manifesta como forma superior dos direitos: direito à liberdade, à individualização na socialização, ao habitat e ao habitar” (LEFEBVRE, 1969, p. 108-124). Estas pautas se relacionam com o direito à moradia, acesso às infraestruturas e equipamentos urbanos de saúde, saneamento, educação, lazer etc. (MONTANER, MUXÍ, 2014), ou seja, do direito à cidade e ao exercício da cidadania.

Todas essas pautas estão inseridas nos Objetivos do Desenvolvimento Sustentável (ODS) e na Agenda 2030, definidos pela Organização das Nações Unidas e firmado pelos seus Estados-membros como um "um apelo global à ação para acabar com a pobreza, proteger o meio ambiente e o clima e garantir que as pessoas, em todos os lugares, possam desfrutar de paz e de prosperidade" (ONU, 2015). A temática deste Projeto está articulada de maneira integrada a todos os 17 ODS, não apenas limitando-se àqueles mais específicos da redução das desigualdades (ODS10) ou às cidades e comunidades sustentáveis (ODS11).

Referindo-se especificamente aBeira-Trilhos, compreende-se como a população acampada, o território concedido e ocupado e a condição de negação de direitos, de segregação socioespacial, de estigmatização social e de subcidadania. Estas reflexões de SCORSATTO (2019) denotam a internalização das experiências e conhecimentos gerados pela Extensão, provocando aquilo que defendem Tommasino e Cano (2016) com uma Extensão ativa, crítica e com potencial transformador da realidade do território e dos conhecimentos dos estudantes participantes do Projeto. 
Os dados apresentados a seguir foram coletados dos relatórios de monitoramento da situação do direito à moradia em Beira-Trilhos de Passo Fundo, publicado pela CDHPF - Comissão de Direitos Humanos de Passo Fundo (CDHPF, 2016). 0 número de famílias entrevistadas em 2015 para a realização dessa pesquisa de atualização de dados foi de 200 unidades, em uma amostragem das 1.500 famílias pesquisadas no levantamento de 2008 (GT BEIRA-TRILHOS, 2008). 0 relatório destaca o aumento da ocupação - observado empiricamente, sem dados atualizados, com uma estimativa de que tenha havido um aumento em torno de $40 \%$ da quantidade de ocupantes, tendo havido adensamento das áreas ocupadas e ocupação de áreas que ainda não estavam ocupadas. De acordo com o levantamento, os moradores são caracterizados como baixa renda: dos entrevistados $25 \%$ apresentam renda familiar de até um salário mínimo; $40 \%$, um; $23 \%$, dois; e somente $8 \%$, acima de três salários mínimos.

Com relação às razões para morar em Beira-Trilho (Figura 3), para a maioria é em consequência da falta de alternativas habitacionais, já que $51 \%$ dos entrevistados moram no local porque "não têm condições de comprar lote e construir em outro local"; $21 \%$ dizem ter "comprado" o direito de morar; $15 \%$ dizem morar ali para "livrar-se do aluguel"; $7 \%$ dizem que "sempre morou ali", sendo que para os outros $6 \%$ são vários motivos (como aluguel mais barato, próximo de familiares, não tem outro local para ir).

Figura 3 - Beira-Trillhos: razões para ocupar o territoório.

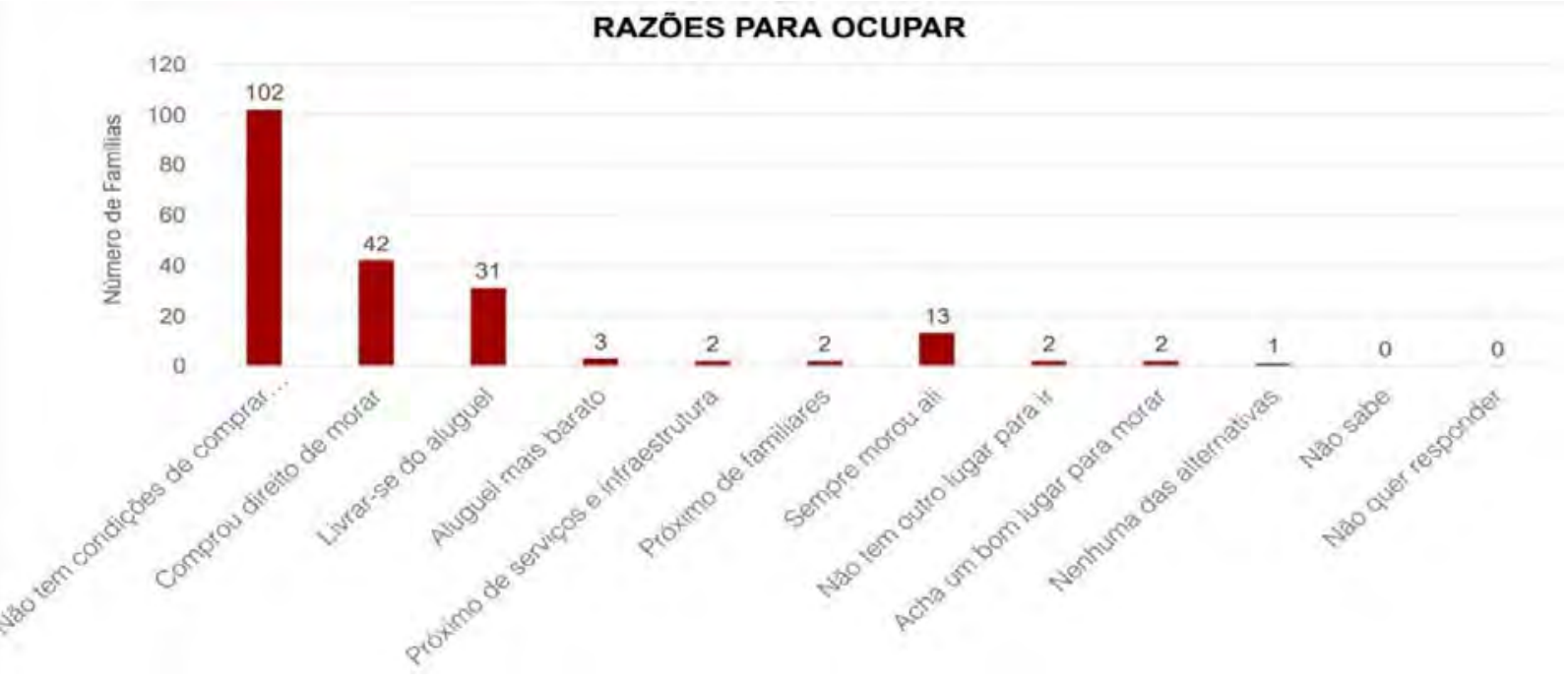

FONTE: SCORSATTO, 2019.

Confirma-se que há uma grande parcela da ocupação, a maior parte dela, que está consolidada em razão do tempo de ocupação, tendo em vista que 60\% ocupam este território há mais de 11 anos, inclusive com disponibilidades parciais às infraestruturas de água e energia elétrica, e contribuições aos impostos municipais.

Com relação ao risco de morar nos locais próximos aos trilhos, o relatório destaca que a manutenção continua insuficiente e inadequada, seguindo sem haver qualquer tipo de impedimento para o acesso à área operacional, exceto cercas de arame farpado em pequenos trechos. A percepção do risco é notada por $41 \%$ dos moradores entrevistados, e, dos que o notam, $57 \%$ acham que é muito baixo, mas $15 \%$ o acham muito alto, $16 \%$ o acham alto e $10 \%$, médio (somados estes chega-se a $41 \%$ ).

Dentre os principais tipos de risco para os que percebem-nos está o desabamento, atropelamento e descarrilamento, notando-se que, para os moradores o que mais aumenta o risco é o transporte de cargas perigosas, a ausência de isolamento da área operacional, a alta velocidade do trem e a falta de manutenção dos trilhos e dormentes. Quanto à solução de segurança, aparece com mais ênfase: fazer muro de contenção (11\%), proibir transporte de cargas perigosas (10\%), sendo a retirada das casas da área operacional (3\%); outras soluções diversas foram também apontadas nas respostas.

Sobre a relação dos moradores com o local, a pesquisa mostra que $76 \%$ diz gostar muito de morar "no Beira-Trilho", sendo que $18 \%$ diz gostar um pouco e somente $5 \%$ diz não gostar. Quanto à possibilidade de morar em outro local, caso pudesse: $36 \%$ diz que moraria com certeza; $31 \%$ que talvez moraria e $28 \%$ que nunca moraria (note-se que entre os que estão em dúvida e os que se recusam se chega a $59 \%$ dos entrevistados); há uma disposição condicionada para sair do local, caso fosse obrigado a sair, já que, para 
$68 \%$ dos entrevistados aceitaria, mas só sairia se fosse para um local melhor, mas $26 \%$ diz que não aceitaria e resistiria de todas as formas para ficar, sendo que somente $4 \%$ sairia com gosto. Esta avaliação dos moradores revela uma estreita relação com o território, sejam pelos aspectos fundiários da "propriedade" ou ao seu direito de ocupá-lo (independentemente das suas razões) mas, principalmente, pelo sentimento de pertencimento ao local com suas conexões afetivas e comunitárias.

A Figura 4 sintetiza o posicionamento da população; no que diz respeito à melhor solução para a situação, para $77 \%$ dos moradores entrevistados a solução é retirar os trilhos e transformar toda a área em bairro, enquanto para $17 \%$ manter os trilhos, mas com a criação de condições de segurança (muro de contenção) e urbanização, indicando que a construção de soluções continua a exigir um enfrentamento sistêmico e que envolva diretamente os moradores/as na sua construção.

Figura 4 - Beira-Trillhos: solução adequada para a situação.

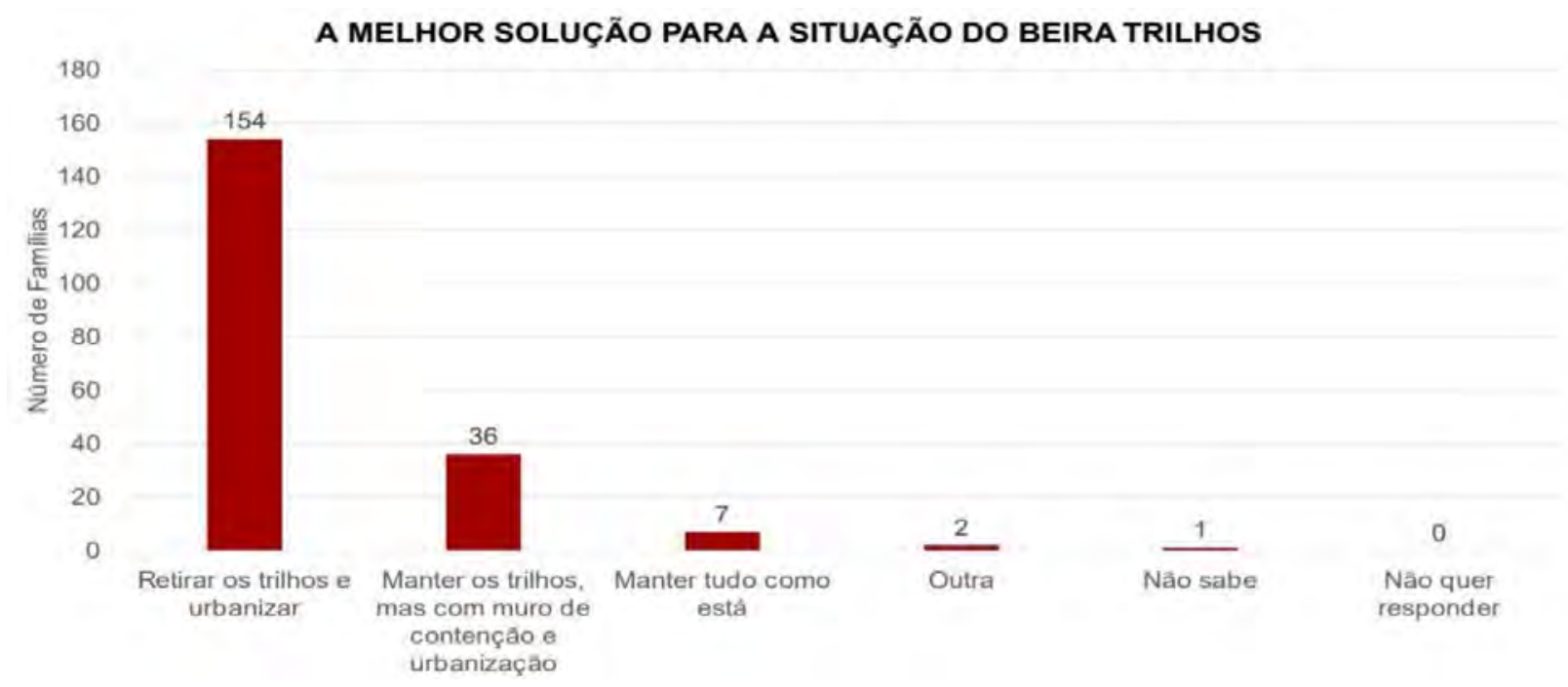

FONTE: SCORSATTO, 2019.

A falta de políticas públicas para atender especificamente a esta população continua existindo e nem mesmo há previsão de uma atenção sistemática para a problemática, pois os diversos Planos que têm sido elaborados nos últimos anos não tratam do tema e, quando o tratam, o fazem de forma tangencial e insuficiente. Cabe mencionar que o trecho em estudo atualmente está inoperante, porém sem perspectivas de uma nova proposta de ocupação.

A nuvem de etiquetas (Figura 5) é fruto de entrevistas realizadas com três repartições administrativas da Prefeitura Municipal de Passo Fundo adjacentes à temática (Meio Ambiente, Habitação e Planejamento) e de interlocuções no espaço Beira-Trilhos dos bairros Valinhos e Vera Cruz, extraídas ao longo do percurso das experiências extensionistas. A experiência de entrevistas com representantes das pastas municipais se deu de forma presencial, não gravada, onde os entrevistados respondiam algumas perguntas discursivas e tinham possibilidade de levantar outros temas e questionamentos pertinentes à discussão. Por sua vez, os discursos mencionados pela população Beira-Trilhos são fragmentos de conversas informais ao longo das atividades extensionistas e de materiais audiovisuais gravados na área. A nuvem de etiquetas é uma composição do autor destacando elementos convergentes e que apareceram majoritariamente nessas interlocuções.

Os discursos destacados ressaltam elementos de compreensões, incompreensões, certezas e dúvidas de ambos os 'lados' sobre a realidade deste território. Este elemento gráfico traduz os diferentes níveis de proximidade e familiaridade com a discussão e aponta para elementos centrais sobre a experiência do lugar, seja ela feita a partir de dentro, ou seja, de quem vive na ocupação, ou de quem olha para a ocupação, que aqui poder-se-ia dizer, de fora (SCORSATTO, 2019). 
Figura 5 - Relatos do lugar.

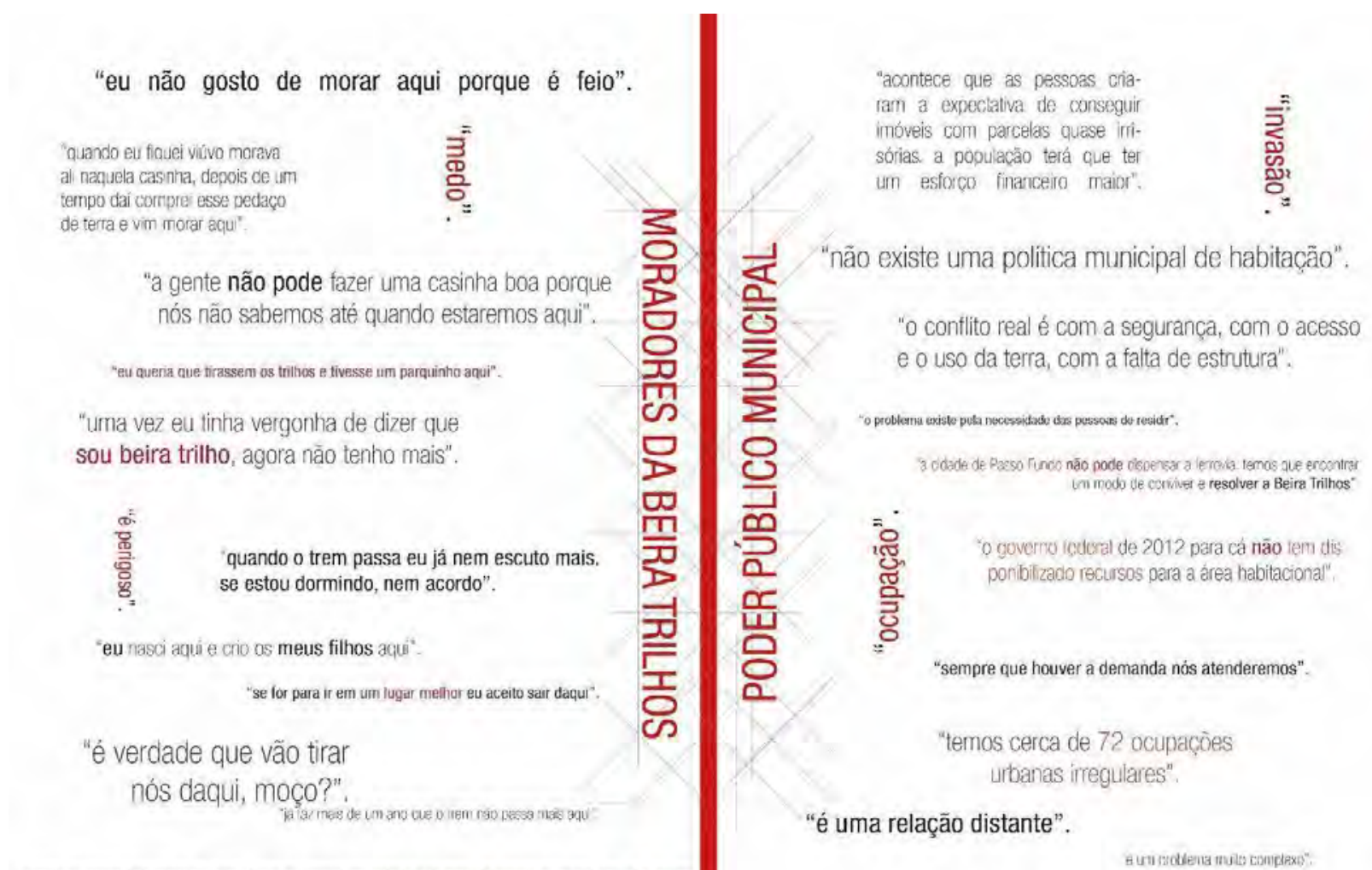

FONTE: SCORSATTO, 2019.

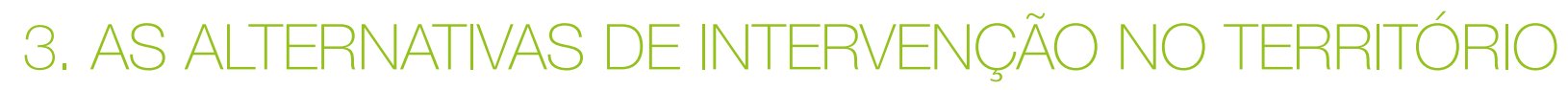

\subsection{Repertorização das intervenções urbanas em ferrovias}

Nos âmbitos do Projeto de Extensão Universitária, diferentes atividades foram desenvolvidas a fim de ampliar os diagnósticos urbanos e sociais e apresentar alternativas para esta problemática; nesse sentido, a repertorização tem como objetivo mostrar modelos de intervenções similares internacionais e nacionais. Tendo em vista a situação atual da comunidade Beira-Trilhos, as indagações referentes às possíveis soluções e alternativas para uma melhoria desta condição são fundamentais. Desse modo, apresentam-se tais estudos de caso como forma de possibilidade de avanço (FRANDOLOSO et al., 2019).

Um destes estudos de intervenções situa-se no complexo de Manguinhos, no Rio de Janeiro (BROKEN CITY, 2011). Os desenvolvimentos desses projetos de escala urbana, agrupados ao Programa Favela-Bairro, foram um projeto administrado pela cidade. 0 objetivo do Programa foi de integrar as favelas à cidade, introduzindo infraestrutura e serviços de facilitação. A abordagem da equipe do Arquiteto e Urbanista Jorge Mario Jauregui se concentra no potencial existente das favelas, e tem, assim, como diretrizes projetuais, não iniciar um novo plano, mas, sim, introduzir elementos como praças para reuniões públicas, centros comunitários, centros de saúde e parques.

Para análise, considerou-se pontualmente a elevação da via férrea e a criação, abaixo dela de uma área de lazer unida a um espaço cívico, reunindo serviços, equipamentos e espaços públicos, como bibliotecas e novos núcleos habitacionais - Figura 6 . A equipe de projeto também definiu critérios para a inclusão dos bairros adjacentes, abordando acessibilidade, e a reorganização das centralidades. 
Figura 6 - Complexo de Manguinhos - Rio de Janeiro.

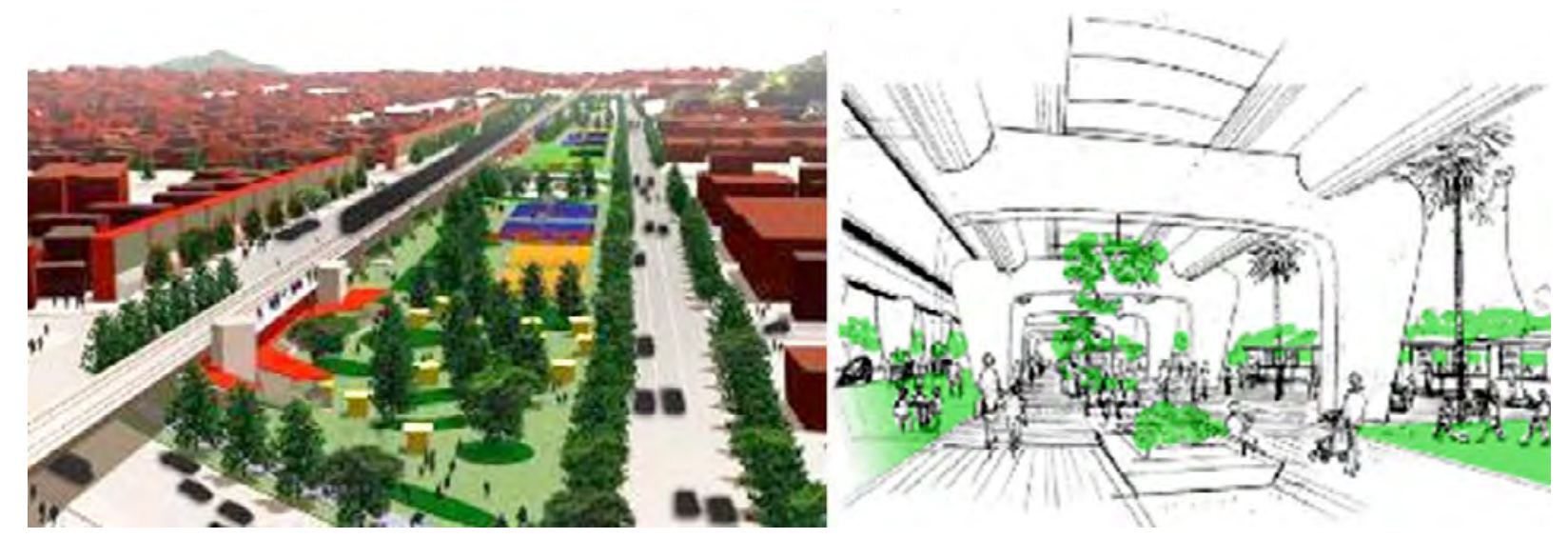

FONTE: BROKEN CITY, 2011.v

0 Projeto planeja a integração socioespacial de um território dividido pelos muros da linha do trem, que parte o complexo ao meio. Foi idealizado para esta área de intervenção um projeto paisagístico que transformasse a qualidade ambiental do entorno (espaços, vegetações, atividades e construções). Esse espaço linear tem a intenção de se tornar um conector de setores, promovendo um ambiente público que atue como articulador social.

Esta conexão com o entorno físico e social se revela bastante adequada para o contexto BeiraTrilhos de Passo Fundo, apontando algumas das abordagens possíveis de implementação, de acordo com o processo de interação dialógica junto aos agentes comunitários que se articulam com o Projeto de Extensão Universitária.

\subsection{Alternativas de ação territorial}

Os referenciais teóricos relacionados aos temas pertinentes à realidade do território apresentam as reflexões frente ao direito à cidade e à moradia, destacando-se aquelas anteriormente comentadas de Harvey (2013), Lefebvre (1969), Maricato (2015) e Rolnik (2017).

Figura 7 - Território Beira-Trillhos Bailrro Valinhos.

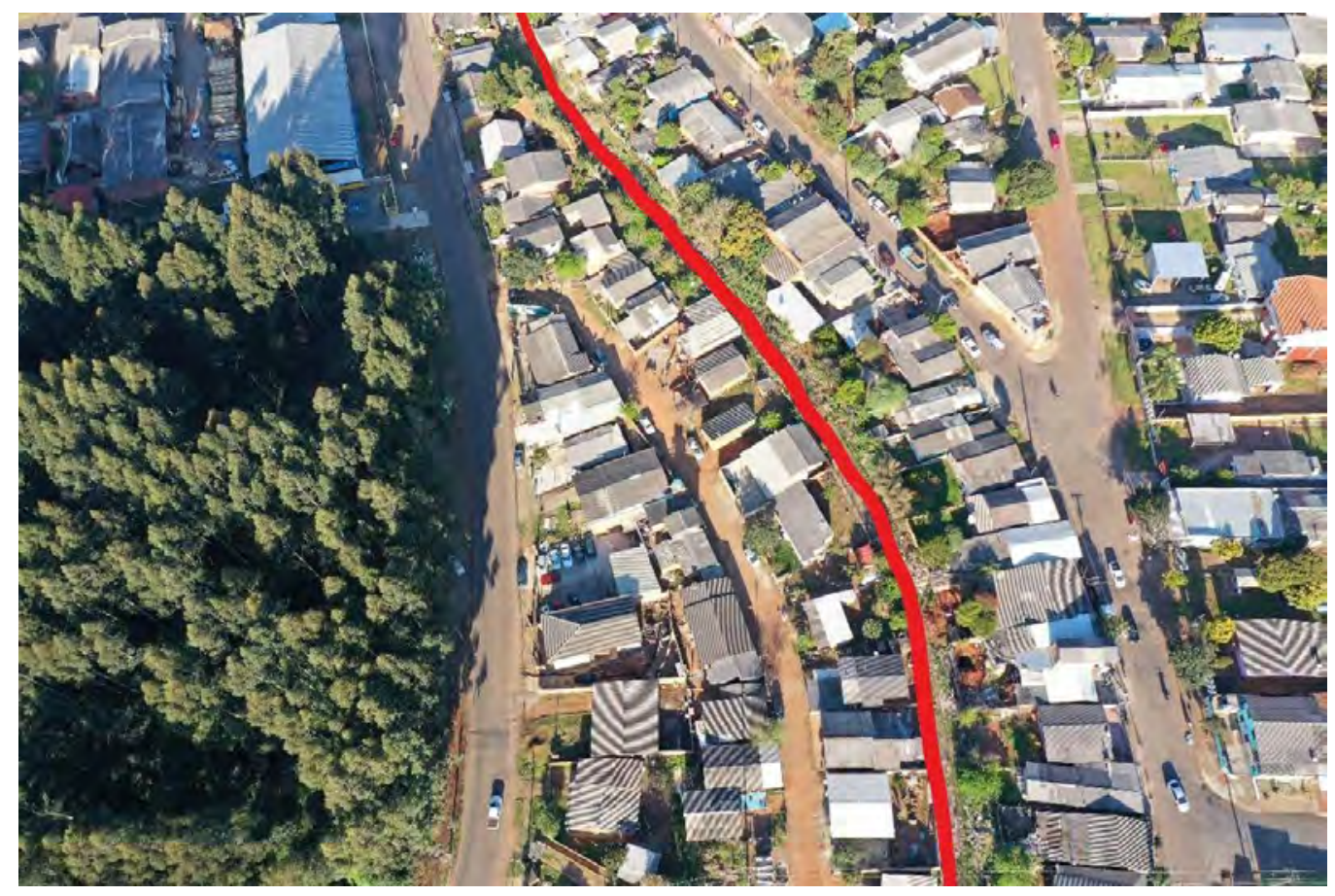

FONTE: autores. 
A leitura deste território representada pelo recorte da Figura 7, onde a linha vermelha mostra a via férrea e se percebem as ocupações nas áreas operacionais e adjacentes, baseou-se em um primeiro momento a partir da interconexão do Projeto de Extensão diretamente com atividade de Ensino, especialmente com a apropriação desta temática no desenvolvimento do trabalho final de Graduação de um dos bolsistas envolvidos no grupo Beira-Trilhos. Scorsatto (2019) desenvolveu as análises urbanísticas e dos dados resultantes dos diagnósticos demográficos da comunidade concentrada no principal vetor de ocupações, nos Bairros Vera Cruz e Valinhos - localizados na porção Noroeste da zona urbana representada na Figura 1, segundo sua característica de maior população e de maior antiguidade, por ser parte do trecho original da via férrea datado de finais do século XIX.

Figura 8 - Setorização do território e eixos norteadores para o Bairro Vera Cruz e Valinhos.

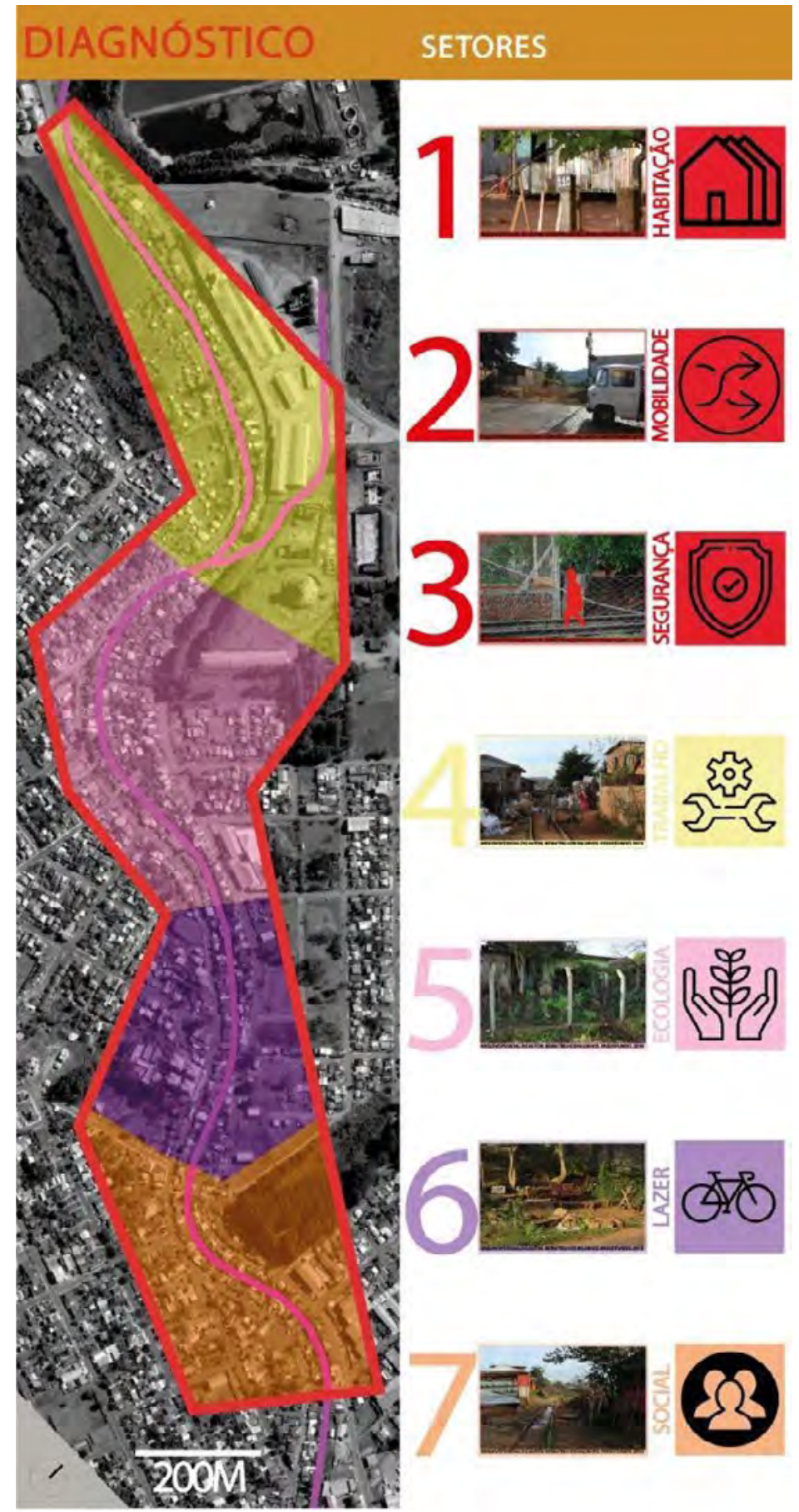

FONTE: SCORSATTO, 2019. 
Esta área de intervenção também é resultante da interação dialógica com a CDHPF, entidade vinculada ao Projeto de Extensão e indispensável propositora de todos os processos envolvendo o espaço Beira-Trilhos, fato que incorpora a comunidade nas discussões, contribuindo com uma perspectiva externa à Universidade, bem como, trazendo também um caráter transdisciplinar e transetorial mais amplo.

Figura 9 - Diagnóstico e propostas para os setores do Bailrro Vera Cruz e Valinhos.

\begin{tabular}{|c|c|c|c|c|}
\hline SETORES & PROBLEMAS & POTENCIALIDADES & DIRETRIZES & ESTRATEGIAS \\
\hline HABIT, & $\begin{array}{l}\text { Sub habitaçá: } \\
\text { isolamento de moradias; } \\
\text { inexistēncia de politica municipal de habitaçăo; } \\
\text { número crescente de ocupantes; } \\
\text { ocupaçăo em terras publicas: } \\
\text { inexisténcia de politica de regularizaçào fundiá. } \\
\text { ria; } \\
\text { ocupaçáo em área operacional da via férrea. }\end{array}$ & $\begin{array}{l}\text { ocupaçấo em área privada; } \\
\text { dreas com potencial para o parcela- } \\
\text { mento do solo no entomo; } \\
\text { existe disposiçáo para a realocaçào: } \\
\text { movimentus sociaise partidos politicos } \\
\text { debatem a mesma situaçáo em muni. } \\
\text { cipios da regiao; }\end{array}$ & $\begin{array}{l}\text { 1-Promover a regularizaçáo fundi- } \\
\text { arria: } \\
\text { 2-Garantir a funçáo social da pro- } \\
\text { priedade; } \\
\text { 3-Criar novos núdeos habitacio- } \\
\text { nais. }\end{array}$ & $\begin{array}{l}\text { 1. Permanència de edificaçōes } \\
\text { locadas em areas não operacio- } \\
\text { nals; } \\
\text { 2. Parcelamento do solo; } \\
\text { 3. Alocaçáo de moradias. }\end{array}$ \\
\hline MOBI & 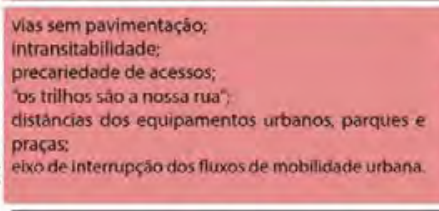 & $\begin{array}{l}\text { Caminhos de conexáo peatonal entre as } \\
\text { moradias; } \\
\text { "os trilhos sato a nossa rua"; } \\
\text { eixo linear de conexdo entre bairros; } \\
\text { presença de modal ferrovílrio no munici- } \\
\text { pio; } \\
\text { trens de carga ahastecem a cidade; } \\
\text { o transporte fertoviàrio movimenta a eco- } \\
\text { nomia local e reglonal: }\end{array}$ & $\begin{array}{l}\text { 1. Reestabelecer conexóes in- } \\
\text { terrompidas; } \\
2 \text { Valorizar eintensificar o tráfe- } \\
\text { go usual dos pedestres; } \\
\text { 3- Criar novos modais de trans- } \\
\text { porte. }\end{array}$ & $\begin{array}{l}\text { 1. Novo traçado de vias; } \\
\text { 2. Infraestrutura favorável ao pe- } \\
\text { destrianismo; } \\
\text { 3. Infraestrutura favorável aos } \\
\text { meios de locomoçáo sustentaveis. }\end{array}$ \\
\hline SEG & $\begin{array}{l}\text { Falta de manutençãa da via fèrrea e da ḋea ope- } \\
\text { racional; } \\
\text { transportes de carga de alto risco; } \\
\text { inexistencia ou fragilidade do saneamento básico; } \\
\text { alagamentos: } \\
\text { inexistência de equipamentos urbanos sociais. }\end{array}$ & $\begin{array}{l}\text { há mais de } 15 \text { meses o trem náo opera } \\
\text { nesse trecho da ferrovia; } \\
\text { programa nacional de segurança ferrovi- } \\
\text { dria em áreas urbanas: } \\
\text { área operacionai de } 20 \text { metros para cada } \\
\text { lado da ferrovia: } \\
\text { órgáo nacionaise internacionais fazemo } \\
\text { moritoramento da situaçáo Beira Trilhus. }\end{array}$ & $\begin{array}{l}\text { 1- Quallicicar rede de infraestru- } \\
\text { tura urbana: } \\
\text { 2. Propor espaços de apropria- } \\
\text { ça da cidade. }\end{array}$ & $\begin{array}{l}\text { 1. Ampliar a rede de iluminaçáo } \\
\text { pública: } \\
\text { 2- Novos espaços para atividades } \\
\text { coletivas saudáveis. }\end{array}$ \\
\hline TRAE & $\begin{array}{l}\text { desemprego; } \\
\text { exclusajo das vagas de emprego por ser Beira Trithosi } \\
\text { espaços inapropriados para as praticas de trabalho } \\
\text { exercidas; } \\
\text { acúmulo de residuos sólidos; } \\
\text { inexisténcia de cooperativa. sindicato ou associaçå } \\
\text { de trabalhadores: } \\
\text { sub empregos. }\end{array}$ & $\begin{array}{l}\text { grupos familiares trabalham em ativi- } \\
\text { dades em comum; } \\
\text { alternativas de trabalho; } \\
\text { inserçăo no distrito industrial; } \\
\text { prática de trabalho exercida; } \\
\text { proximidade com vias arteriais e rodo- } \\
\text { vias. }\end{array}$ & $\begin{array}{l}\text { 1.-Criar espaços adequados para as } \\
\text { praticas locais de trabalho; } \\
\text { 2-Potencializar associaçóes comu. } \\
\text { nitárias com vinculo de trabalho. }\end{array}$ & $\begin{array}{l}\text { 1- Espaço que organize e possibi- } \\
\text { lite a execução das etapas de cole- } \\
\text { ta, separaça, armazenamentoe co- } \\
\text { mercializaçáo de residuos sólidos; e } \\
\text { 2- Local de reunlaso e sociabiliza- } \\
\text { çáo para as pessoas associadas. }\end{array}$ \\
\hline ECOLC & $\begin{array}{l}\text { Inexisténcia ou fragilidade de saneamento básico; } \\
\text { efluentes irrigam as hortas; } \\
\text { proximidade com área de proteçáo de recursos hidrt- } \\
\text { cos e corrego: } \\
\text { falta de assiténcia técnica para implementaçáa adequa- } \\
\text { da de } \\
\text { produçáo alimentar; } \\
\text { proximidade com a estaçáo de tratamento de esgotos; } \\
\text { falta de áreas verdes públicas. }\end{array}$ & $\begin{array}{l}\text { hortas; } \\
\text { alargamento da área entre as vias; } \\
\text { maiores lotes; } \\
\text { práticas de cultivo de alimentos para } \\
\text { consumo próprio e troca; } \\
\text { cultivo de jardins; } \\
\text { plantas de grande porte nos lotes criam } \\
\text { massas de vegetaçáo. }\end{array}$ & $\begin{array}{l}\text { 1- Requalificar áreas públi- } \\
\text { cas; } \\
\text { 2- Potencializar práticas lo- } \\
\text { cais de cultivo. }\end{array}$ & $\begin{array}{l}\text { 1- Arborizaçảo; } \\
\text { 2. Produzir alimentos para con- } \\
\text { sumo, troca e comercializaçáo. }\end{array}$ \\
\hline LAZER & $\begin{array}{l}\text { Inexisténcia ou fragilidade de equipamentos urba- } \\
\text { nos; } \\
\text { distáncias de parques e praças; } \\
\text { depredaçào da praça do bairro; } \\
\text { inexisténcia de mobiliários para permanéncia e en- } \\
\text { tretenimento; } \\
\text { falta de infraestrutura adequada para a prática de es- } \\
\text { portes; }\end{array}$ & $\begin{array}{l}\text { vazios urbanos: } \\
\text { áreas públicas permitem conversáoem } \\
\text { espaços públicos; } \\
\text { trilhos como local de encontro; } \\
\text { vazios urbanos utilizados para práticas } \\
\text { esportivas. }\end{array}$ & $\begin{array}{l}\text { 1- Ativar células de entreteni- } \\
\text { mento no espaço urbano. }\end{array}$ & $\begin{array}{l}\text { 1- Novos espaços públicos; } \\
\text { 2- Urbanismo colaborativo; } \\
\text { 3- Instalaçáo de infraestrutura so- } \\
\text { cial. }\end{array}$ \\
\hline SOCIAL & 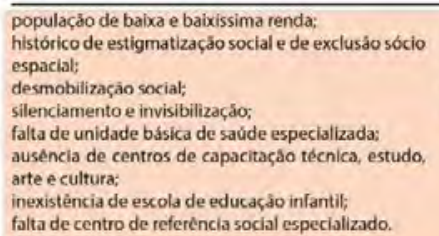 & $\begin{array}{l}\text { templos como espaço de encontro } \\
\text { comunitário e sociabilizaçáo; } \\
\text { organizaçáo comunitária; } \\
\text { pertença ao território. }\end{array}$ & $\begin{array}{l}\text { 1- Ampliar rede de assistên- } \\
\text { cia social; } \\
\text { 2- Instalar infraestruturas de } \\
\text { educaçáo e cultura; } \\
\text { 3-Potencializar as redes deco- } \\
\text { municaçăo. }\end{array}$ & $\begin{array}{l}\text { 1. Implantar infraestruturas so- } \\
\text { ciais e urbanas. }\end{array}$ \\
\hline
\end{tabular}

FONTE: SCORSATTO, 2019.

Complementando estas análises e diagnósticos, tomando em conta a percepção da comunidade local expressada pela Figura 5, foi desenvolvida uma proposta de projeto urbano para esse território, de acordo com a setorização apresentada na Figura 8, de acordo com as especificidades de cada um dos elementos físicos e sociais do território. Considerando como princípios balizadores da proposta de intervenção o planejamento urbano integrado, o desenvolvimento sustentável, a abordagem bottom-up, a cidade como lugar de encontro, a escala humana, a moradia adequada e o pedestrianismo, estruturou-se a proposta organizando-a em eixos norteadores que são: habitação, mobilidade, segurança (área total da intervenção), trabalho, ecologia, lazer e social (territórios parciais da área de intervenção). Isso não significa uma proposição segregacional de usos, mas uma intensificação das vocações locais diagnosticadas na análise. A Figura 9 apresenta as propostas para cada um dos setores e eixos de acordo com a Figura 8. 
Para cada eixo, foram identificados os problemas e as potencialidades, construídas diretrizes, estratégias e propostas de intervenção. Dentre as proposições do programa de necessidades está o parcelamento do solo de vazios urbanos do entorno, realocação de residências da área operacional para esses vazios, regularização fundiária das ocupações em áreas privadas e implantação de um parque linear como um eixo verde e conector. Igualmente novos equipamentos urbanos foram propostos de maneira a suprir as demandas de educação, saúde, cultura e lazer.

\section{Figura 10 - Implantação e estratégias de planejamento.}

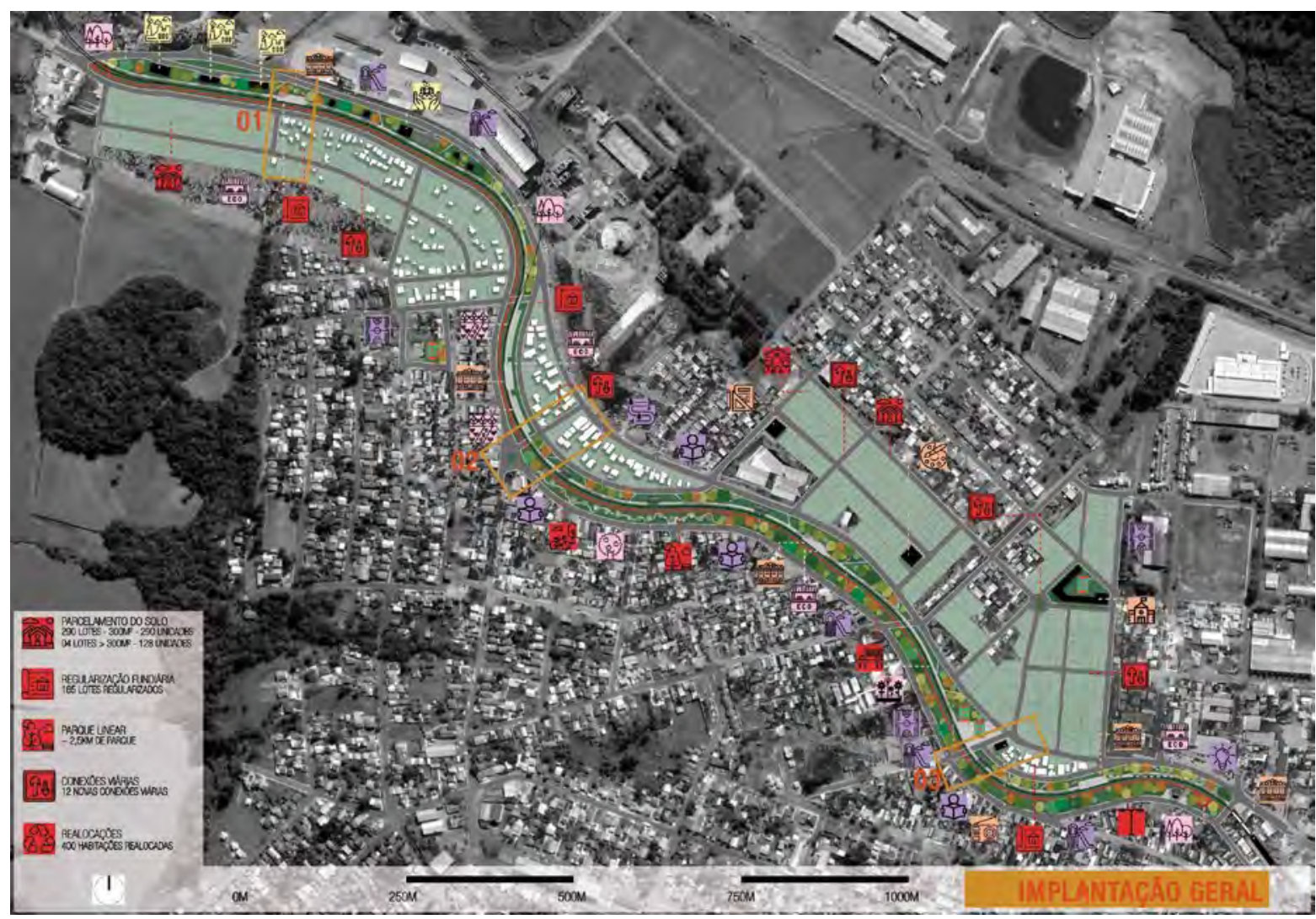

FONTE: SCORSATTO, 2019

A representação da implantação destas estratégias de planejamento demonstradas na Figura 10, permitem qualificar o espaço público e a organização dos espaços privados gerados, fazendo a conexão entre a morfologia urbana existente, caracterizada pelo limite determinado pela via férrea, e a proposta. Conexão esta verificada tanto no sentido longitudinal paralelo à ferrovia por meio de um parque linear, mas também apresentando transversalidades e articulações entre cada um dos "lados", atualmente segmentados e sem conexão viária formal.

Cabe ressaltar que a permanência dos trilhos contribui para a construção da memória da comunidade local, mas também da cidade como um todo, nesta proposta a ser utilizada como espaço de lazer e de cultura com a implementação de um equipamento urbano denominado pelo autor como "vagões da cidadania" consistem em equipamentos transitórios com biblioteca, espaços multiuso e unidades básicas de saúde para triagem e encaminhamentos.

A partir dos contextos determinados recentemente pela Pandemia da Covid-19, a etapa de difusão e discussão externa com a comunidade do território, prevista na programação das ações, está condicionada aos procedimentos e determinações institucionais externos.

Para finalizar, a Extensão Universitária contribui com o crescimento profissional dos alunos extensionistas pois a ação da Universidade em conjunto à comunidade possibilita o compartilhamento do conhecimento adquirido em sala de aula, ou no ambiente acadêmico de maneira geral. 0 impacto da prática extensionista se dá pelo fato de articular o conhecimento científico com as necessidades reais da comunidade Beira-Trilho, mostrando na prática o papel social da Arquitetura e Urbanismo, que, muitas vezes, no ambiente acadêmico, não tem uma dimensão integral e integrada; dessa forma, os alunos extensionistas interagem e contribuem para a transformação da realidade social. 
Segundo relato de uma das bolsistas do Programa de Apoio Institucional a Discentes de Extensão e Assuntos Comunitários - PAIDEX -, a prática extensionista transforma: "Como pessoa, evoluí, pois, na minha opinião, quando ingressamos na Extensão, começamos a ver o mundo com outros olhos." (BOFF, 2019). Percebe-se então, que além do olhar crítico e profissional sobre a situação do território, com saberes técnicos e referências já apresentadas neste artigo, a Extensão atende as funções sociais da UPF como uma Universidade Comunitária, cumprindo "a missão de formar profissionais cidadãos, éticos e preparados para as transformações sociais. [...] [sendo a] extensão universitária parte inerente ao fazer acadêmico buscando uma aproximação com a realidade social" (UPF, 2021). A prática extensionista atravessa e transcende o aluno, já que a Extensão leva em conta os saberes e fazeres populares e o auxilia a tornar-se um profissional que perceba e seja sensível às necessidades do meio.

\section{REFLEXÕES E CONCLUSÕES}

Diante de um cenário de violação dos direitos humanos e de omissão das partes responsáveis, o Projeto Beira-Trilhos desenvolve um trabalho de caráter multidisciplinar que possibilita espaços de troca entre a Universidade e a comunidade, comprometendo-se em não deixar cair no esquecimento os debates acerca da realidade dessa população.

Dada a complexidade desses casos e da situação em que as ocupações se encontram, pesquisar e obter resultados viáveis para a melhoria destas condições, além de enxergar as necessidades que são deixadas de lado, são contribuições extremamente necessárias para a melhoria das circunstâncias em que a população Beira-Trilhos se encontra.

Os estudos visam obter embasamento para futuras intervenções na área, que só será possível com esse tipo de Metodologia de Pesquisa e Extensão Universitária; desta forma se faz pertinente relacionar os estudos com a situação atual, comparar, refletir, analisar como estão sendo propostas as relações com a população e a ferrovia; só assim, as soluções podem se tornar mais efetivas e promover a melhoria da qualidade de vida nestes espaços urbanos.

Esta contribuição também se faz como subsídio de alternativas para as ações legais em curso, para a retomada do controle da concessionária da via férrea e de seu território, o que implica, provavelmente, na remoção das unidades habitacionais que se encontram dentro das áreas operacionais, porém não operativas atualmente.

Com relação aos objetivos de desenvolver uma discussão e promover ações projetuais, embora aqui seja apenas uma das inúmeras possibilidades de intervenção, o Projeto de Extensão contribui de forma positiva para a conexão do tecido urbano e na recuperação destas áreas atualmente segregadas no sentido social, ambiental e urbanístico. Ademais, as experiências multidisciplinares contribuem de forma positiva na construção de conhecimentos e vivências dos estudantes, com posturas ativas e transformadoras da prática extensionista.

Nesse sentido, o presente trabalho traz à tona a discussão sobre o direito à cidade, integrando os aspectos humanos e dos grupos sociais ao desenho e morfologia urbana caracterizada pela segregação que as ferrovias, em sua maioria, carregam como limites ou barreiras de conexões do tecido urbano. Estes contextos apresentados no território Beira-Trilhos, carregam um distanciamento social à moradia, às infraestruturas, à qualidade ambiental. Infelizmente este panorama não é um caso isolado, mas o reflexo de políticas urbanas e humanas locais, regionais e/ou nacionais desarticuladas e negligentes, identificadas em diferentes cidades brasileiras.

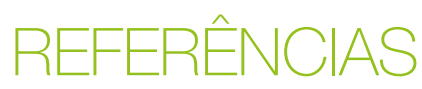

\section{BOFF, Natália Costa. Roteiro para elaboração de relatório dos alunos extensionistas (bolsistas PAIDEX e voluntários). Passo Fundo: VREAC - UPF, 2019.}

BRASIL. Ministério da Educação. Conselho Nacional de Educação. Câmara de Educação Superior. Resolução n07, de 18 de dezembro de 2018. Estabelece as Diretrizes para a Extensão na Educação Superior Brasileira e regimenta o disposto na Meta 12.7 da Lei no 13.005/2014. Brasília: MEC, 2018.

BROKEN CITY. Manguinhos Complex. Public Space in the context of the divided society Urban, Social and Environmental Articulation PAC - Programa de Aceleração do Crescimento. Rio de Janeiro, 2011. Disponível em: http://www.jauregui.arq.br/broken_city.html?fbclid=IwAR3rrG5NDb3anhA42BSPy34vkTZb9Xzkg_ QV07Tdt8fc5L3q42I2wodp1rM. Acesso em: 15 abr. 2020. 
CARBONARI, Paulo César; VASCONCELLOS, Carla Portal. Projeto de Extensão Beira-Trilhos. Passo Fundo: VRPEAC - UPF, 2016.

CDHPF. COMISSÃO DE DIREITOS HUMANOS DE PASSO FUNDO. Direito humano à moradia adequada.

Desvelando o beira-trilho: situação e perspectivas. Relatório de estudos de caso. Passo Fundo: IFIBE, 2005.

CDHPF. COMISSÃO DE DIREITOS HUMANOS DE PASSO FUNDO. Relatório de monitoramento da situação.

Direito humano à moradia adequada no beira-trilho de Passo Fundo 10 anos depois. Passo Fundo: CDHF, 2016.

DALMOLIN, Bernadete Maria; MORETTO, Clenir Maria (Org.) Política de responsabilidade social 2013/2016. Passo Fundo: Universidade de Passo Fundo, 2014.

FRANDOLOSO, Marcos Antonio Leite et al. Beira-Trilhos: a implementação do direito à moradia e à cidade. In: CONGRESSO BRASILEIRO DE ARQUITETOS: Espaço e Democracia, 21, 2019, Porto Alegre. Anais Caderno de Resumos. Porto Alegre: IAB-RS, 2019, p. 89. Disponível em: https://www.21cba.com.br/Site/CbaOnline/Anais. Acesso em: 20 out. 2020.

FRANDOLOSO, Marcos Antonio Leite; SCORSATTO, Eduardo Nichespois; VASCONCELLOS, Carla Portal. A extensão acadêmica e a aproximação ao território Beira-Trilhos - Passo Fundo. In: JORNADAS DE EXTENSÃO DO MERCOSUL, 7, 2019, Passo Fundo. Anais... Passo Fundo, UPF, 2019.

FRANDOLOSO, Marcos Antonio Leite; SCORSATTO, Eduardo Nichespois. "Beira-Trilhos": the implementation of the right to housing and the city by an extension project in Southern Brazil. In: WORLD SYMPOSIUM ON SOCIAL RESPONSIBILITY AND SUSTAINABILITY, 2, 2020, Curitiba. Disponível em: https://dl4sd.org/course/view. php?id=12. Acesso em: 23 jul. 2020. [In: Social Responsibility and Sustainability: adressing challenges and creating opportunities. Berlin: Springer, in press.]

GEHL, Jan. Cidades para pessoas. 3. ed. São Paulo: Perspectiva, 2015.

GELPI, Adriana; KALIL, Rosa Maria Locatelli. A cidade comentada: expressões urbanas e glossário em urbanismo. Passo Fundo: Universidade de Passo Fundo, 2016.

GT BEIRA-TRILHO. Relatório de dados: levantamento socioeconômico da população beira-trilho de Passo Fundo. Passo Fundo, GT Beira Trilho, 2008.

HARVEY, David. 0 direito à cidade. Piauí, 82, jul. 2013. Disponível em: https://piaui.folha.uol.com.br/materia/odireito-a-cidade/. Acesso em: 28 maio 2020.

IBGE. Instituto Brasileiro de Geografia e Estatística. Passo Fundo: panorama. Brasília: IBGE, 2020. Disponível em: https://cidades.ibge.gov.br/brasil/rs/passo-fundo/panorama. Acesso em: 20 out. 2020.

KALIL, Rosa Maria Locatelli et al. (2007). Cidade de Todos: diagnóstico sobre situação habitacional da Beira Trilho. In: ENCUENTRO ULACAV, XIII, Valparaíso - Chile. Actas. Disponível em: http://www.invi.uchile.cl/ derechociudad/index.html. Acesso em: 30 maio 2020.

LEFEBVRE, Henri. 0 direito à cidade. São Paulo: Documentos, 1969.

MARICATO, Ermínia. Para entender a crise urbana. São Paulo: Expressão Popular, 2015.

MONTANER, Josep Maria; MUXÍ, Zaida. Arquitetura e política: ensaios para mundos alternativos. São Paulo: Gustavo Gili, 2014.

ONU. Organização das Nações Unidas. Objetivos do desenvolvimento Sustentável. ONU, 2015. Disponível em: https://brasil.un.org/pt-br/sdgs. Acesso em: 20 out. 2020.

ROLNIK, Raquel. Territórios em conflito: São Paulo: espaço, história e política. São Paulo: Editora Três Estrelas, 2017.

SCORSATTO, Eduardo Nichespois. Reestruturação urbana: da segregação à revitalização na Beira-Trilhos. 
Monografia (Pesquisa Orientada em Arquitetura e Urbanismo Trabalho Final de Graduação), Curso de Arquitetura e Urbanismo, Universidade de Passo Fundo. Passo Fundo: UPF, 2019.

TOMMASINO, Humberto; CANO, Augustín. Modelos de extensión universitaria en las universidades latinoamericanas en el siglo XXI: tendencias y controversias. Universidades, año LXVI, n. 67, ene-mar 2016, p. 7-24. Disponível em: https://www.researchgate.net/profile/Humberto_Tommasino e https://www.researchgate. net/profile/Humberto_Tommasino. Acesso em: 18 ago. 2020.

UPF. Universidade de Passo Fundo. Vice-Reitoria de Extensão e Assuntos Comunitários. Política de extensão e assuntos comunitários. Passo Fundo: Ed. Universidade de Passo Fundo, 2017.

UPF. Universidade de Passo Fundo. Vice-Reitoria de Extensão e Assuntos Comunitários. A Universidade próxima da comunidade. Disponível em: https://www.upf.br/extensao. Acesso em: 13 de abril 2021. 